\title{
IUELTAL
}

\section{Exploring the Influence of Computer-Based National Examination on English Teaching Process: Voices from Indonesian EFL Teachers}

\author{
Moch. Said Mardjuki \\ SMK Negeri 3 Kupang \\ e-mail: saidmardjuki@gmail.com \\ Arif Husein Lubis \\ Universitas Pendidikan Indonesia \\ e-mail:lubis_ah@upi.edu
}

\begin{abstract}
:
Currently, the government of Indonesia has implemented a computer-based test for the national examination for secondary schools in Indonesia. It is believed that the administration of computer-based national examination (CBNE) would address some challenges related to dishonesty and validity. The present study is aimed to investigate the teachers' perception of the implementation of CBNE and its influence on the English teachers' teaching process. This study employed a qualitative design in which semi-structured interviews and document analysis from the English teachers' lesson plans were done to obtain comprehensive data. The analysis results revealed that the teachers held a positive view of the implementation of CBNE because it is effective and efficient in terms of the process, security, scoring, and cost-saving. Besides, the components of the teaching process influenced by the administration of CBNE were extra class, teaching materials, teaching methods, and teaching activities. However, the implementation of CBNE still led to several challenges in terms of technical problems and a lack of computer experts. Therefore, by conducting an internship with other supporting parties, those challenges would be minimized.
\end{abstract}

Keywords: $C B N E$, challenges, English teaching process, perception 


\section{Introduction}

Recently, the Indonesia Ministry of Education and Culture (MOEC) has decided to implement a Computer-based national examination (CBNE) to some eligible secondary schools, according to the website of the MOEC (2019). The government believes that implementing this kind of assessment will improve the national examination integrity index by the intervention of information and communication technology in its national examination. However, the administration of CBNE spends more time than paper-based tests spending three days, which may lead to the validity issue of CBTNE (Hapli, Kristiyono, \& Alamsyah, 2017).

Thus, the present study is aimed to investigate the English teachers' perception and attitude toward CBNE and its influences on their teaching process. The computer-based test is a kind of testing that utilizes computer-assisted mode for delivering the questions along with the answering process (National Education Standard Office, 2017). Moreover, Dudeney and Hockly (2007) define CBT as a new phenomenon of testing in which the assistance of the computer provides a range of different types of tests and examinations. Furthermore, Parshall, Spray, Kalohn, and Davey (2002) acknowledge that CBT is more enriching than the standardized testing, which utilizes paper-based as a "state of the art." In other words, CBT can be defined as a new stream in delivering standardized testing by employing computer devices.

Harmiyuni and Sailan (2016) conducted a study related to the students' and teachers' perception towards the implementation of CBNE revealed that the students' perceived positive perceptions and were pleased to have CBNE. Thus, from the teachers' side, they understood that the implementation of CBNE would have some advantages and disadvantages. The benefits related to effectiveness, budgeting, and dishonesty. On the other side, the obstacles are those related to technical problems, including the availability of the computer, internet, and electricity access. Likewise, Pakpahan (2016) in his research, also revealed that there are some benefits and barriers to administrating CBNE. The benefits deal with cost-saving in printing and distributing the test ease in the scoring process, and enabling exam certificate printing done after the test has been administered. However, the challenges are wide-area coverage, computer specification and internet access, and stakeholder policy in supporting the administration of CBNE.

Tayeb, Aziz, Ismail, and Khan (2014) conducted research related to the effect of the general secondary English examination (GSEE) on teaching and learning in Yemen. Their study found that the test significantly contributed to the development of teaching methodology and learning styles as the vital components of the teaching and learning process. Likewise, Sukyadi and Mardiani (2011) conducted a research on the washback of English national examination (ENE) to the teaching and learning process. They found that the administration of ENE itself has contributed to the students' learning process, particularly in the third grade, in which the teachers tend to test-oriented teaching, practice, and strategies development. 


\section{Literature Review}

\subsection{The use of CBT in EFL testing}

Educational Testing Service in 1998 introduced the most substantial move to CBT in EFL testing by implementing a computer-based test as a delivering the TOEFL (Educational Testing Service, 1998). It comprises listening, structure, reading, and writing. It is the development of ETS in responding to the importance of electronic devices in delivering the test, including several multiple skills as a long-term objective. It is different from the paperbased test, which includes the writing section as institutional demands to gain comprehensive measurement.

The development of CBT is mainly used as a placement test or to measure student's language proficiency, which appears in almost all universities around the world. For example, the Pearson Test of English Academic (PTE Academic) "is a computer-based academic English language test aimed at non-native English speakers wanting to study abroad. It tests Reading, Writing, Listening, and Speaking" (Exam English, 2014). Cambridge English computer-based exams provide several tests; three of them are first for school, advanced, and proficiency. Generally, those types of tests cover reading, listening, and writing. First for school is intended for B2 level students (senior high). Advanced is designed for $C_{1}$ level students (diploma). Proficiency is designed for $C_{2}$ level students (university) (Cambridge English, 2017).

The implementation of CBT in EFL testing has its drawbacks and advantages. As regards of the drawbacks, the application of CBT in EFL testing faces several challenges. They include the lack of test-takers' computer literacy, lack of test item variation, typically in the form of multiple-choice tests, and the difficulty to measure productive skills (speaking and writing) leading to rigid assessment form (Alderson, 2000; Brown, 1997; Dunkel, 1999). Test-takers perceive a lack of computer literacy challenging in doing CBT. The implementation is done by using computers. They have to be familiar with moving the mouse and keyboard. The lack of item variation in CBT since it is typically in the form of multiple-choice tests, yes/no questions, and cloze and gap-filling items are commonly used. Thus, regarding measure productive skills: speaking and writing, human raters and e-rater are the combinations to measure those skills (Suvorov \& Hegelheimer, 2013). It is used due to mediate the testtakers contents in writing or speaking since it is hard to assess by employing e-rater. Moreover, Cantillon, Irish, and Sales (2004), in their research, found that there were some challenges during the implementation of the computer-based test. The challenges are lack of facilities, technical error during the test, and lack of test security. It is because both the teachers and students are unfamiliar with the test mediated by computers as the primary tool.

There are several benefits of CBT as a mode of delivering the assessment. It may reduce the procedure of scoring the exam, the budget in terms of printing and distributing the test, the security of the database, the opportunity of direct feedback, and personalized testing (Alderson, 2000; Brown, 1997; Dunkel, 1999). The administration of assessing CBT results saves time compared to the process of scoring in paper-based testing. Thus, CBT is cost saving since it is delivered through online, semi-online, and offline in the form of CD ROMs. One of the advantages of the implementation of CBT is security, which has several test item banks in the way of a database. The result of the test in CBT will be displayed. Thus, the 
test-takers would have flexibility: time and place in conducting CBT rather than a paperbased test in which the test-takers should wait for the test instructions from the supervisor.

\subsection{CBT in Indonesian context: The case of English subject}

Computer-Based National Examination (henceforth CBNE) in Indonesia is delivered by semi online in which the internet connection is needed only in the beginning and at the end of the test. In the beginning, the students register as the test-takers. The questions are sent to the school's server. Whereas, at the end of the test, it deals with addressing the result of the students into a central server (NESO, 2017). According to NESO (2019, pp. 64-69), the computer-based national examination of English subject consists of fifty numbers of questions for junior high and senior high levels. The test administration takes approximately 120 minutes (two hours). For senior high level, the items are divided into two main sections: listening and reading. The listening section consists of fifteen numbers, which are divided into three parts: pictures, questions and responses, short dialogues, and short talks. Meanwhile, the reading section comprises of three parts: incomplete conversations, cloze texts, and reading comprehension. The total number of the reading section is thirty-five questions. The test types of the reading section in CBNE are different from the paper-based test national examination. For example, in the reading section from 2005 to 2016 for vocational high school, the reading section consisted of four parts, including incomplete dialogues, error recognition, cloze texts, and reading comprehension. It is due to the government would like to avoid the teachers' test-oriented teaching instead of materialsoriented teaching as mandated in the curriculum.

\section{4 (CB)NE and EFL Teaching}

National Examination is categorized as high-stake testing. High-stake testing can be defined as a kind of test that has a significant influence on students' further career or study (Ferman, 2004). This high-stake testing of English language subjects mostly refers to the global benchmark, such as The Common European Framework of Reference (CEFR). Previous research in an international context has noted that such a global parameter influences the language learning, teaching, and assessment (Agirdag \& Vanlaar, 2018 in 18 countries; Ilc \& Stopar, 2015 in Slovenia; Juknevičienè \& Šeškauskienè, 2014 in Lithuania; Mutereko, 2018 in South Africa). In the last fifteen years, National Examination itself is designed in a new mode of testing; that is computer-based testing in addition to paperbased testing. The administration of the National Examination in Indonesia is aimed at mapping the school's quality, as one of the university admissions, and as the information as well as the feedback for the school, according to Indonesian President Regulation Number 13 the Year 2015(Ministry of the State Secretariat, 2015). It consists of several subjects depends on the study program. For example, for a genetic study program, it includes mathematics, Indonesian, English, Chemistry, Physics, and Biology. On the other hand, the vocational high school consists of four subjects: Indonesian, mathematics, English, and productive subject.

As a result of the administration of high-stake testing, Spratt (2005) described that there are several components on the teaching process affected by high-stake testing. The components are time allocation, materials, teaching methods, feelings, and attitudes. Time allocation relates to extra classes in organizing the students to get used to the test and the testing types. The second component is teaching materials in which it has to be following 
the learning goal. Indeed, it refers to the textbook or coursebook used by the teachers in delivering teaching materials in the classroom. The third component is the teaching method in which it relates to the way teachers employ the teaching strategies to make the students succeed in the examination. The last component is feelings and attitudes in which it relates to their fear of the National Examination and its effects.

Furthermore, previous research has examined the influence of the administration of highstakes testing in educational institutions on the teaching and learning process, which is known as washback (Pan, 2009). The former deals with how the teachers convey the teaching and learning process, which is based on the curriculum. It is also motivating the students to learn to accomplish the study as well as improving their learning, and the teacher itself will selective in choosing teaching materials. The latter deals with how the teachers teach the test to their students, but neglect the school functions to prepare the students' lifelong learning. The test will lead to anxiety from both teachers and students in terms of their success in the examination.

Sulistyo (2009) conducted a small survey to explore the English teachers' perspectives on the implementation of English national examination. The findings revealed that the teachers agreed that the English national examination had an impact on the improvement of the students' learning attitudes and the teachers' teaching strategies. However, they argued that the exam could potentially limit the allocation for classroom-based assessment since the students need to have adequate preparation to be successful in doing the exam later.

More comprehensively, Furaidah, Saukah, and Widiati (2015) compared the perceptions of English teachers from high-achieving and low-achieving schools on the washback of English national examination in the Indonesian context. The findings demonstrated that what the teachers perceived on the students' capacity to deal with the exam determined the depth of washback they experienced. The washback included teaching focus, time allocation, classroom activities, and materials.

Aziez (2011) investigated the corpus of English vocabularies covered in the English national examination texts for four years of administration. The results revealed that there need collaborative actions to raise the students' awareness on improving their vocabulary mastery through teachers, textbook designers, and test protocols. He argued that the English national examination had a great influence on the adjustment of the vocabulary level in the textbooks.

Furthermore, Ibrahim (2014) examined the importance of maximizing reading strategies to help students deal with the English national examination. His research exhibited a significant increase in the students' UN-test-model scores after enrolling in a quasiexperimental study. The findings underscored that the English national examination also influenced the teachers' teaching style, especially in promoting the potentials of reading strategies to the students.

Recently, Daeli, Hutapea, Gea, Lestari, and Saragih (2020) identified the reading questions of Computer-Based National Examination in Indonesia for senior high school students. The results showed that there were five types of reading comprehension questions covered in the test: literal comprehension, reorganization or reinterpretation, inference, evaluation, 
and personal response. Their discussion further explains that the types of reading questions of the CBENE have an impact on the developers of the learning materials to suit the texts with the objectives.

Previous research mentioned before demonstrates that there are several influences that national examination of English subject generates from the preparation level to the evaluation level of the English teaching and learning process. However, the exploration of the influence of CBNE as a new model of high-stakes testing on the English teachers' teaching process is still scarce. As regards the administration of CBENE, it would be fostering the use of information and communication technology at the school level, which impacts the teachers' teaching process (UNESCO, 2011). Thus, the importance of the integration of ICT in classroom context seems essential as the demand of the $21^{\text {st }}$ century, and it is in line with the latest curriculum, 2013 Curriculum. The curriculum pinpoints the importance of employing information technology in the classroom context as one of the strategies in promoting learner autonomy to prepare the students to develop higher-order thinking skills. It is also supported by the study conducted by Boevé, Meijer, Albers, Beetsma, and Bosker (2015) revealed that there was no discrepancy between students' performance between the paper-based and the computer-based test. It is due to the students who live in the information technology era.

Although there are previous studies on the students' perceptions toward CBNE in Indonesia, there were limited numbers of studies on the English teachers' perceptions and attitudes toward CBNE and its influences in EFL teachers' teaching process. Thus, the study may contribute valuable information for English teachers regarding their beliefs on the implementation of CBNE in their teaching process. The following research questions drive this study.

1. How do the teachers perceive the implementation of CBNE of English subject?

2. What are the challenges encountered by the teachers?

3. How do CBNE of English subject influence the teaching and learning process?

The present study is expected to contribute to theoretical, practical, and professional benefits. Regarding educational benefits, the findings of the study will enhance theories of language testing and evaluation. In terms of practical benefits, it is expected to provide a realistic description of the influence of CBNE for secondary school level as an input for government decisions.

\section{Research Methodology}

\subsection{Design}

The present study employed a descriptive qualitative research design since it deals with humans' experiences from which a detailed description is going to be displayed (Sandelowski, 2000). This study was designed to seek the English teachers' perception of CBNE and its influences on their teaching process.

\subsection{Site and Participants}

Three English teachers in Bandung were purposively selected as the participants of the study. Two teachers were from senior high schools and one English teacher from vocational high school. They have had more than six years of teaching experience. Most of the 
participants have experienced in teaching English to all grades either at senior or vocational schools. Interestingly, one of them has experienced in teaching at an English course. Besides, their schools have implemented the 2013 Curriculum in which they have administered CBNE since 2016. The participants' teaching hours ranged from four to thirtytwo hours a week. One of the participants has the most minimum teaching hours since she has to accomplish her master's degree at one state university in Bandung. Besides, they represent urban and sub-urban demography. It would give in-depth information not only related to their perception but also their experience in facilitating the teaching and learning process.

\subsection{Instruments}

This study employed a semi-structured interview and document analysis to triangulate the data. The semi-structured interview consisted of 12 questions functioning as the primary data, while the document analysis in the form of teachers' lesson plans featured as the supporting data. It is chosen since it provides information related to teaching objectives, teaching methods, teaching materials, activities, and assessment. Several steps were involved. First, select the research participants purposively. Second, conduct the interview, before performing the interview, the researcher asked for permission from the participants for the interview to be recorded and transcribed. Later on, they were asked to hand in a copy of their teaching lesson plan, respectively. After the interview was being transcribed, the transcription was sent back to the interviewee to recheck the data accuracy.

\subsection{Data Analysis Procedures}

The data analysis employed Miles and Huberman's (1994) framework. The data from the interview were classified into two major themes: English teachers' perception of CBNE and its influence on their teaching process. After categorizing the ideas, data will be displayed in the form of a response based on each research question. The data interpretation for each research question is drawn in general. After being checked by the interviewee, the transcripts were proofread related to any errors in grammar. Similarly, the relevant documents were first analyzed by the researchers by coding them interpretively. Then, the constant comparative method was employed to obtain consistency of data from the transcripts and the documents.

\section{Findings}

\subsection{EFL Teachers' Perceptions of the Implementation of CBNE}

The participants' teaching experience mostly has got more than six years, meaning that they have experienced in both two types of national examinations: paper-based and computer-based. Regarding the implementation of $C B N E$, the participants were asked about their definitions related to CBNE. Nancy defined it as a test assisted by a computer. In line with Nancy, Windy described it as the government's effort to use the computer to do the national exam. On the other hand, Hanna did not provide any detail definitions related to the CBNE.

As regards the CBNE itself, the participants believed that CBNE is not different from paperbased, only in the method of delivery. Regarding the content and type of the test items of CBNE, most of the participants have the same perception that CBNE has no discrepancy in 
terms of time allocation, number of test items, and types of tests. It also consists of two sections: listening and reading. The following are the descriptions of CBNE from the participants' view:

The time allocation is similar with a paper test that is two hours. I assume those methods only to facilitate the test itself. The results are similar with the previous result conducted by paper-based test, only the media which facilitate the test that make differences. In the room, there are two staffs on school operator and the supervisors from the other schools. The fully stand by in the room is only the supervisors from the other schools. (Nancy)

Moreover, the administration of CBNE has emerged a positive perception in terms of effectiveness and efficiency. Hanna argued:

It will make the whole process [of evaluations] more efficient. And then, the school just need that they need to adapt and to be honest, it also makes the test easier and then, it is free paper so it is eco-friendlier. The government will be able to control in efficient, effective, and it costs cheaper

Related to the rationale of the administration of CBNE it relates to the demand for ICT development and its integration. Thus, it is also an effort from the government to familiarize the use of computers to the students. The following was what the participants said about the rationale of the implementation of CBNE:

Because we all know that this is digital era, everyone most has the ability or skills to use that kind of tools. so that this CBT help them to be more familiar and use the tools more frequently. (Hanna)

It because we must catch up with the demands of global era. I think we must accept this CBT. This is also the requirement from the government to be conducted. (Nancy)

The document analysis results from the teachers' lesson plans also portrayed that the teachers emphasized the utilization of ICT in their teaching process. Some of the identified teaching aids were laptops, smartphones, projectors, and videos. They also allowed the students to bring their mobile phones. It was because they encouraged the students to use the internet to explore the learning resources, such as from The Jakarta Post and other educational websites.

However, the learning outcome did not portray the significance of ICT integration in the teaching and learning process, even though they have conducted CBNE. It does not characterize its influences on the students learning the outcome. The following are representatives of the interviewees' statements:

I think the method of test both paper and computer have nothing to do with the students' career, but the score from the test, of course has great influence for their career. I assume those methods only to facilitate the test itself. For example, the score of their final examination can be used like then, for applying to AKMIL, to AKPOL because they still use final examination score as basic consideration. (Nancy)

Not too many, because now we use the computer just for examination but actually in daily [teaching] activity we usually also use the computer. So, it does not affect 
too much I think. Because their career depends on the other exams. For example, SBMPTN (a kind of national university entry examination in Indonesia) if they want to go to the college they have to pass the exam first. (Windy)

I am not really sure how this CBNE describe or portray my students' capability in English. I am not really that person into standardized testing so that I do not think it really describes my students' capability authentically. CBT I think, it boosts or accelerates for the teachers and the students to get more familiar and use this tools more frequently.

Hanna, however, has a different view. She did not believe in standardized testing. She argues that standardized testing would not be able to portray students' abilities in certain subjects, mainly English.

\subsection{The Challenges of CBNE}

In conducting CBNE, there were several obstacles, such as: lack of ICT facilities, technical problems, and human resources. Some argued:

There is a weakness because the limitation of the computer that we have. The big deal for them is about how to use the computer. (Windy)

I think it will quite hard the students to have them to be more familiar with the equipment. They only have access to that kind of tools in terms of internet, computer and laptops that are provided in the school. It is the first time; everyone is still learning. (Hanna)

We still find lot of difficulties even though before the test we have conducted the simulation. For example, like in the middle of the test suddenly the electricity run off. but in the reality, lots of technical errors can make it ineffective design and make students very exhausted. The one who experts in computer are very limited at the school. (Nancy)

Based on the responses above, the students' illiteracy in using computer becomes a significant concern when they take the CBNE. Besides, the computer experts and the situational conditions in which ordinary teachers became as operators or proctors.

\subsection{The Influences of CBNE on the Teaching Process}

The implementation of CBNE in the Indonesian education system has influenced several components of teaching. Thus, the administration of CBNE itself has triggered the stakeholders, particularly at the school level, to prepare it well. There would be several policies to ensure whether CBNE is administered as it is expected, as well as to get a better score. The following explanations were provided for giving detailed information related to the school's regulation on CBENE.

That we call as pengayaan (enrichment). Last [academic] year we did that [enrichment] because of our school's principal regulation. (Windy)

Of course, they are always an extra class for twelfth-grade students before they are facing national examination whether it is CBNE or paper-based. (Hanna) 
However, Nancy claimed that there were no additional classes or extra time in the preparation of CBNE either at her school or her regency. However, Windy rejected the implementation of an enrichment class at her school. She argued:

Because students already have too much time in school. They spend time up to three in the afternoon. So, we have extra time for pengayaan (enrichment) which is really hard for students also..

Besides preparing the students to administer the CBNE by providing additional class, the school's regulation was also emphasized on the ICT infrastructures as well as to conduct simulation class. One participant described:

They prepare all the facilities including the room, the computers, the maintenance for the computers. They conduct some simulations for students. It is expected they will feel accustomed with that kind of test but only one so far for preparing the next exam. (Nancy)

Thus, the materials for the twelfth grade are based on the previous national examination test. Hanna described that the materials were taken from the last test, three years ago; 2013 to 2015 . It is also supported by the analysis of teachers' lesson plans in which there was no lesson plan provided to teach the students of the twelfth grade at the extra class. Moreover, most of them blended the materials to prepare their students in facing CBENE if there was no extra class provided by the school. The following are their descriptions of the materials used at the twelfth grade:

In the third grades we still have two meetings in a week. We teach them based on that kompetensi kelulusan (competence of graduation). I design my teaching materials to meet those objectives as it is stated in the competences of graduation. Not only CBNE, but for paper-based also particularly for the third-grade students we have to manage the time how to finish the curriculum first and then how to make enrichment class for them to face the national examination. (Windy)

The content of the test really influences my teaching planning when I taught in the third grade. It only focusses on reading and listening ignoring the other four skills that is speaking and writing. So, the effect probably will influence the reading and the listening ability. The materials [were taken] from the previous testing. (Nancy)

The findings from their lesson plans also supported it. They demonstrated the impact of CBNE on the selection of learning activities in the classroom. For example, the students were asked to read and answer the questions about the announcement texts encompassing the main idea, implicit and explicit meaning from the text, and synonym. They also used multiple-choice and essay tests for their assessment, particularly for the twelfth graders. Even, in this case, they introduced part of computer-based English national examination to the students.

Windy got feedback for her teaching materials. The result of the national examination also influenced them.

CBNE or even paper-based, we will get the feedback from the result. In the scoring, we can see what are the weaknesses. So, the weakness is about listening skills. The feedback that we have to improve in the next semester. 
Regarding teaching activities, the participants agreed that the student-centered cooperative approach is the appropriate way to be conducted in the classroom.

The learning process nowadays it needs to be the students-centered and then, involve them in a small group and let them discuss and collaborate and discuss to solve the problems or we give the problem for the cooperative learning so that even though we use the computer or without the computer, the methods still quite the same. (Hanna)

The data from the lesson plans also supported the data from the interview. The participants emphasized the implementation of student-centered learning in their classes, particularly for the tenth and eleventh graders. They asked the students to make their dialogues or texts based on the situation. For example, the students were assigned to announce all the students about a school event. So, every class should prepare a performance for this activity. They composed the dialogues about giving and asking for direction.

Moreover, the participants agreed that the administration of CBNE motivates them to integrate appropriate ICTs in the teaching and learning process. They argued:

I usually use language laboratory and make them familiar with the computer. They have the presentation. I encourage them to have practice more about listening skills. They use PowerPoint. They use their computer and then they bring it to us and delivering the presentation. (Windy)

It is inspiring me that both of teachers and students need to implement or include this tool [computer] into their learning process. I had my students to submit their assignment through the email and other teachers not only me they have use internet; they have to use computer for submitting an assignment or project from the students to teachers. (Hanna)

CBT makes me encourage to integrate technology in the classroom. It is expected by the assistance of CBT I should conduct the test based on computer also, by using Google forms, Edmodo, or the other technology applications. (Nancy)

The evidence from their lesson plans corroborated the findings. They wrote that they utilized ICT both in delivering their teaching materials and in assessing their students' works. Regarding project-based learning, the teachers reported that they assigned the students to make a short video under the guidance from the scoring rubric. E-portfolios were also identified in their lesson plans. Then, the students' works were submitted to the teachers via email, WhatsApp or LINE and revised.

However, most of the participants agreed that the administration of national examination through either paper or computer modes hindered several language skills to be taught. A participant acknowledged:

I think the existence of final examination in language teaching hampers the purpose of language process demanded by 2013 Curriculum because it only focusses on reading and listening ignoring the other two skills that is speaking and writing. (Nancy) 
As a consequence, they seemed to teach the test than to teach the materials from the syllabus. Those materials were based on the previous tests, or it can be downloaded from the internet. One of them argued:

I think we have or hold more exercises. For example, like from previous examination tests or we find out kisi-kisi [soal] (a kind of test-item prediction). So, more practicing, answering questions, and then give them clues how to answer reading tests. How you can find the answer in the text. Give them more testing strategy to pass the test. (Windy)

\section{Discussion}

Regarding the definition of a computer-based national examination, most of the participants defined it as a test assisted by a computer. This definition is similar to the description from NESO (2017) and Dudeney and Hockly (2007), describing it as a kind of testing that utilizes computer-assisted for delivering questions along with the answering process.

Thus, it can be noted that the participants have the same perceptions related to CBNE. It emphasizes that the implementation of CBNE is not different from the paper-based. The standard of CBNE, as described at NESO (2017), states that the CBNE is a new mode to administer national examination in terms of replacing the paper-based one. Then, there were no discrepancy between the students' performances on the paper-based tests and CBNE. It echoes with Boevé et al. (2015). Therefore, there would be no discrepancy in terms of the type of test, number of criteria, time allocation, and the procedures. The difference lies in the session for CBNE, in which the implementation is divided into three sessions each day. Each session consists of twenty students. It is contrasting to paper-based in which the students have the same time to do the test. This difference may lead to the validity issue of CBNE (Hapli et al., 2017).

Related to the effectiveness and efficiency of CBNE, it is seen that CBNE would decrease the state budget to administer the national examination and shorten the cycles of distributing and scoring the test. The distribution of national examination on paper-based and its scoring process is impacted by the state budget in which, in each academic year, the government allocates more budget to administer the national examination. These findings of the study concur with the previous research conducted by Harmiyuni and Sailan (2016) and Pakpahan (2016). Thus, the integrity in conducting national examination becomes the primary concern of the government to minimize it by implementing CBNE. It is believed that by implementing $C B N E$, this kind of problem would be decreased since it has numerous bank test items (Alderson, 2000; Brown, 1997; Dunkel, 1999), and the students would only focus on the monitor. Thus, it would also minimize the intervention of the school, including teachers who would like to help the students in terms of getting a better score since it is semi online CBT in which the test begins only in the beginning and at the end of the test (NESO, 2017).

Regarding the rationale of conducting $C B N E$, the participants pinpoint that the implementation of CBNE becomes a response to the importance of ICT development and the integration of ICT in education, particularly in terms of the teaching and learning process. It is also due to global and industrial demands which require the students to have 
competences in administrating ICT. These findings are in line with what has been found by UNESCO (2011) related to the significance of ICT integration in the teaching and learning process.

The result of the National examination, either paper or computer modes, does not portray the students' English ability, and it does not influence their future career. It is because the national examination aims to be school mapping and one of the requirements to enter into university (NESO, 2017). The present study does not reveal a positive learning outcome related to the implementation of CBNE on their teaching and learning process.

Regarding the influences of CBNE on the teaching process, the present study depicted this that the teaching components influenced by the administration of CBNE were time allocation, teaching materials, teaching methods, and teaching activities. This founding concurs with the study conducted by Spratt (2005) that the administration of high-stake testing has several implications for the components of teaching. The components are time allocation, teaching materials, teaching methods, feelings, and attitudes. However, the time allocation expands through additional classes or enrichment to ensure the students' familiarity with the test and to get the maximum score. This finding is relevant to the research conducted by Sukyadi and Mardiani (2011), describing that national examination will impact the extension of teaching hours. Moreover, based on the Indonesian President Regulation Number 13 the Year 2015 in Ministry of the State Secretariat (2015), the result of the national examination will be used as the school mapping of its quality, feedback, and as one of the requirements for the students to continue their study at the university level. This study also found that several institutions, such as military academics, still used the national examination result as a basis of admission to enroll in the academy.

Related to the teaching materials, the participants mostly referred to the previous tests to make their students familiar with the test types. Thus, it also found that their teaching materials were based on the feedback and graduate standard competences as the government gave those. The former was related to the national examination result in which each school would have after the implementation of the national examination. The participants analyzed which types of tests that their students found difficult, and it would be as valuable information for them to improve in the upcoming semester. The latter dealt with graduate standard competencies that might appear on the national examination. These findings were similar to what has been found by Sukyadi and Mardiani (2011), acknowledging that in the preparation of national examination, the teachers tend to use or modified their teaching materials based on the test types. Interestingly, this study found that the graduation competencies became one of the major concerns for leading the participants to use it as the objectives of their teaching process.

However, from the analysis of teachers' lesson plans, it was hard to find any evidence related teaching materials and also the steps in the teaching process that influenced by the administration of CBNE on their teaching plans. Thus, regarding the additional classes or enrichment, the teachers did not have any specific lesson plan which guided them in delivering teaching materials. They focused on teaching the students about the test strategy and get the students to become familiar with it (Sukyadi \& Mardiani, 2011). This finding indicated a significant discrepancy with other studies conducted in Indonesia in 
which it revealed that the additional classes held by several schools did not guide the teaching plan merely based on the previous tests and graduate standard competences.

As regards the teaching method used by the participants, the present study found that the participants tended to use cooperative learning in which the students become the central part of the teaching and learning process. This method is done due to the policy of the school in the preparation to face the national examination. Therefore, it happened only in the teaching process that the materials are based on the syllabus. Meanwhile, in the enrichment class, they preferred to test-oriented teaching. Sukyadi and Mardiani (2011) and Tayeb, Aziz, Ismail, and Khan (2014) found that teaching methods were influenced by the implementation of high-stakes testing to achieve a better score in the examination.

Furthermore, the majority of the participants were encouraged to integrate ICT-based on their teaching process as the demand for the importance of ICT in education, particularly in the teaching and learning process (UNESCO, 2011). Thus, they encouraged the students to use the computer in and outside the classroom. Since it is a cooperative method, they used PowerPoint slides and videos downloaded from the internet to present their projects. The students also used email to submit their assignments to their teachers. However, a discrepancy is identified in the teaching activities at the twelfth grade. They focus on teaching the test to the students only. It was in line with the study conducted by Sukyadi and Mardiani (2011), pointing out that the implementation of national examination led the teachers to teach the test to the students to make them familiar with it.

Based on the responses above, the students' illiteracy in using computer becomes a significant challenge when they take the CBNE. It is in line with Alderson (2000), Brown (1997), and Dunkel (1999), claiming that one of the significant obstacles in conducting CBT was lack of test-takers' computer literacy. Therefore, the government, based on the standard operating procedure from NESO (2017), encourages to minimize the technical problems, including electricity, by conducting an internship with PLN and TELKOM. Interestingly, the computer experts and the situational conditions in which ordinary teachers became as operators or proctors are not covered in the previous research.

\section{Conclusion}

This present study has reported two significant themes based on the analysis of the present study. The first theme is regarding the teachers' perception of the implementation of CBNE. The teachers hold a positive view of the administration of CBNE because it is effective and efficient in terms of the process, security, scoring, and cost-saving. This kind of assessment had no significant differences in terms of test types, test items, and time allocation. The main difference was on the method of delivery. Thus, related to the influences of CBNE on the teaching process, it revealed that the implementation of such national examination influenced several components of teaching, including time allocation, teaching materials, teaching methods, and teaching activities. In terms of time allocation, it led to the school's policy to conduct an extra class or enrichment class to get the students familiar with the test as well as to get a better score in the national examination. Interestingly, there was no teaching lesson plan to guide the participants in delivering their teaching. In terms of teaching materials, the participants designed their contents based on the graduate standard competences and the previous test. In terms of teaching activities, they divided their teaching activities based on the teaching session. At the first meeting, they taught 
based on the syllabus, while at the second meeting, they taught based on the previous tests indicating test-oriented teaching for the students. The last but not least, the challenges in the administration of CBNE were technical constraints and lack of computer experts. Concerning the methodological limitation, further research needs to explore the washback of CBNE through observation.

\section{References}

Agirdag, O., \& Vanlaar, G. (2018). Does More Exposure To The Language Of Instruction Lead To Higher Academic Achievement? A Cross-National Examination. International Journal Of Bilingualism, 22(1), 123-137.

Alderson, J. C. (2000). Technology In Testing: The Present And The Future. System, 28(4), $593-603$.

Aziez, F. (2011). Examining The Vocabulary Levels Of Indonesia's English National Examination Texts. Asian EFL Journal, 51, 16-29.

Boevé, A. J., Meijer, R. R., Albers, C. J., Beetsma, Y., \& Bosker, R. J. (2015). Introducing Computer-Based Testing In High-Stakes Exams In Higher Education: Results Of A Field $\begin{array}{llll}\text { Experiment. Plos } O N E_{1} & 10(12), & 1-14 .\end{array}$ https://doi.org/http://doi.org/10.1371/journal.pone.0143616

Brown, J. D. (1997). Computers In Language Testing: Present Research And Some Future Directions. Language Learning And Technology, 1(1), 44-59.

Cantillon, P., Irish, B., \& Sales, D. (2004). Using Computers For Assessment In Medicine. $B M J, 329(7466), 606-609$.

Ministry Of Education And Culture. (2019). UNBK 2020.

Daeli, N. H., Hutapea, Y. J. N., Gea, F. D. N., Lestari, I., \& Saragih, E. (2020). Identifying Reading Comprehension Questions Of National Examination For Senior High School Students. Journal Of Languages And Language Teaching, 8(1), 83-90.

Dudeney, G., \& Hockly, N. (2007). How To Teach English With Technology. Malaysia: Pearson Education.

Dunkel, P. (1999). Considerations In Developing Or Using Second/Foreign Language Proficiency Computer-Adaptive Tests. Language Learning And Technology, 2(2), 77-93.

Cambridge English. (2017). CEFR Diagram.

Exam English. (2014). PTE. Retrieved November 20, 2017, From https://www.examenglish.com/pte/index.php

Ferman, I. (2004). The Washback Of An EFL National Oral Matriculation. In L. Cheng, Y. Watanabe, \& A. Curtis (Eds.), Washback In Language Testing: Research Contexts And Methods (Pp. 191-210). Mahwah, NJ: Lawrence Erlbaum Associates.

Furaidah, Saukah, A., \& Widiati, U. (2015). Washback Of English National Examination In The Indonesian Context. TEFLIN Journal, 26(1), 36-58.

Hapli, A., Kristiyono, E., \& Alamsyah, Z. (2017). Permasalahan Digital Divide Pada Pelaksanaan Ujian Nasional Berbasis Komputer UNBK Di Indonesia. Retrieved November 20, 2017, From https://mti.binus.ac.id/2017/07/03/Permasalahan-DigitalDivide-Pada-Pelaksanaan-Ujian-Nasional-Berbasis-Komputer-Unbk-Di-Indonesia/

Harmiyuni, \& Sailan, M. (2016). Persepsi Siswa Tentang Pelaksanaan Ujian Nasional Berbasis Computer Di SMK Komputer Mutiara Ilmu Makassar. Jurnal Tomalebbi, 2, 3642. 
Ibrahim, M. S. (2014). Maximizing Reading Strategies: Helping Students In Facing National Examination Of English Subject. Journal Of Education And Practice, 5(13), 124-132.

Ilc, G., \& Stopar, A. (2015). Validating The Slovenian National Alignment To CEFR: The Case Of The B2 Reading Comprehension Examination In English. Language Testing, 32(4), $443-462$.

Juknevičienè, R., \& Šeškauskienè, I. (2014). The National Examination Of English In Lithuania: Searching For Evidence Of CEFR Criterial Achievement Levels. Studies About Language, 25, 88-96.

Miles, B. M., \& Huberman, A. M. (1994). Qualitative Data Analysis: An Expanded Sourcebook. Thousand Oaks: Sage.

Mutereko, S. (2018). Marketisation, Managerialism, And High-Stake Testing: A Tale Teachers' Views On National Assessments In South Africa. International Journal Of Educational Management, 32(4), 568-579.

National Education Standard Office. (2017). Standard Operational Procedures Of National Examination In Academic Year 2016/2017. Jakarta: National Education Standard Office.

National Education Standard Office. (2019). Standard Operational Procedures Of National Examination In Academic Year 2019/2020. Jakarta: National Education Standard Office.

Pakpahan, R. (2016). Model Ujian Nasional Berbasis Komputer: Manfaat Dan Tantangan. Jurnal Pendidikan Dan Kebudayaan, 1(1), 19-35.

Pan, Y. (2009). A Review Of Washback And Its Pedagogical Implications. VNU Journal Of Science, Foreign Languages, 25, 257-263.

Parshall, C. G., Spray, J. A., Kalohn, J. C., \& Davey, T. (2002). Practical Considerations In Computer-Based Testing. New York, NY: Springer.

Sandelowski, M. (2000). Focus On Research Methods Whatever Happened To Qualitative Description? A Journal In Research Of Nursing \& Health, 23, 334-340.

Secretariat, M. Of The S. Indonesian President Regulation. , (2015).

Educational Testing Service. (1998). Computer-Based TOEFL Score User Guide. Princeton, NJ: Educational Testing Service.

Spratt, M. (2005). Washback And The Classroom: The Implications For Teaching And Learning Of Studies Of Washback From Exams. Language Teaching Research, 9(1), 529.

Sukyadi, D., \& Mardiani, R. (2011). The Washback Effect Of The English National Examination (ENE) On English Teachers' Classroom Teaching And Students' Learning. K@Ta, 13(1), 96-111.

Suvorov, R., \& Hegelheimer, V. (2013). Computer-Assisted Language Testing. The Companion To Language Assessment, 2, 594-613.

Tayeb, Y. A., Aziz, M. S. A., Ismail, K., \& Khan, A. B. M. A. (2014). The Washback Effect Of The General Secondary English Examination (GSEE) On Teaching And Learning. GEMA Online Journal Of Language Studies, 14(3), 83-103.

UNESCO. (2011). Unesco ICT Competency Framework For Teachers (2nd Ed.). France: The United Nations Educational, Scientific And Cultural Organization. 